\title{
Characterization of Myelomonocytoid Progenitor Cells with Mesenchymal Differentiation Potential Obtained by Outgrowth from Pancreas Explants
}

\author{
Marc-Estienne Roehrich ${ }^{1}$ and Giuseppe Vassalli ${ }^{1,2}$ \\ ${ }^{1}$ Department of Cardiology, Centre Hospitalier Universitaire Vaudois (CHUV), Avenue du Bugnon, 1011 Lausanne, Switzerland \\ ${ }^{2}$ Molecular Cardiology Laboratory, Fondazione Cardiocentro Ticino, via Tesserete 48, 6900 Lugano, Switzerland
}

Correspondence should be addressed to Giuseppe Vassalli, giuseppe.vassalli@chuv.ch

Received 31 March 2012; Revised 6 June 2012; Accepted 14 June 2012

Academic Editor: Gabriel A. Monteiro

Copyright ( $\odot 2012$ M.-E. Roehrich and G. Vassalli. This is an open access article distributed under the Creative Commons Attribution License, which permits unrestricted use, distribution, and reproduction in any medium, provided the original work is properly cited.

\begin{abstract}
Progenitor cells can be obtained by outgrowth from tissue explants during primary ex vivo tissue culture. We have isolated and characterized cells outgrown from neonatal mouse pancreatic explants. A relatively uniform population of cells showing a distinctive morphology emerged over time in culture. This population expressed monocyte/macrophage and hematopoietic markers $\left(\mathrm{CD}_{11 b^{+}}\right.$and $\left.\mathrm{CD}_{4} 5^{+}\right)$, and some stromal-related markers $\left(\mathrm{CD} 44^{+}\right.$and $\left.\mathrm{CD} 29^{+}\right)$, but not mesenchymal stem cell (MSC)-defining markers $\left(\mathrm{CD} 90^{-}\right.$and $\left.\mathrm{CD} 105^{-}\right)$nor endothelial $\left(\mathrm{CD} 31^{-}\right)$or stem cell-associated markers $\left(\mathrm{CD} 133^{-}\right.$and stem cell antigen-1; Sca-1- ${ }^{-}$. Cells could be maintained in culture as a plastic-adherent monolayer in culture medium (MesenCult MSC) for more than 1 year. Cells spontaneously formed sphere clusters "pancreatospheres" which, however, were nonclonal. When cultured in appropriate media, cells differentiated into multiple mesenchymal lineages (fat, cartilage, and bone). Positive dithizone staining suggested that a subset of cells differentiated into insulin-producing cells. However, further studies are needed to characterize the endocrine potential of these cells. These findings indicate that a myelomonocytoid population from pancreatic explant outgrowths has mesenchymal differentiation potential. These results are in line with recent data onmonocytederivedmesenchymal progenitors (MOMPs).
\end{abstract}

"M.-E. Roehrich passed away whilst this article was in press."

\section{Introduction}

The pancreas is a complex organ consisting of three principal cell types: endocrine islets, exocrine acini, and ducts. Evidence of differentiation of new $\beta$-cells from pancreatic nonislet cells suggests the existence of pancreatic nonendocrine stem/progenitor cells $[1,2]$. New $\beta$-cells may also result from replication of preexisting $\beta$-cells [3], or from progenitor cells originating from the ductal epithelium [46 ] or the exocrine tissue of the pancreas [7-9]. Pancreatic progenitor cells express key transcription factors involved in the embryological development of endocrine cells such as pancreatic and duodenal homeobox factor 1 (Pdx1), neurogenin 3 (Ngn3) and paired box 4 (Pax4), or embryonic markers such as Oct-4 and Nanog, or nestin [10]. Pancreatic progenitor cells have been prospectively isolated by fluorescence-activated cell sorting (FACS) using specific antibodies that recognize cell-surface epitopes expressed by stem/progenitor cells in other tissues, such as CD133, CD117 (c-kit/stem cell factor receptor), ATP-binding cassette (ABC) G2, and mesenchymal stem cell (MSC) markers [11-15].

An alternative method for the isolation of tissue-resident progenitor cells is the explant outgrowth approach. This method does not rely on positive cell selection. Within tissue explants, progenitor cells are located in close proximity to stem cell niches, which regulate stem and progenitor cell 
function [16]. These cells may become activated during ex vivo primary tissue culture, migrate across chemotactic gradients towards the surface of the tissue explant, are shed by it, and form a monolayer. Primary tissue cultures of the adult or embryonic pancreas have been described extensively [17]. In contrast, data on pancreas explant cell outgrowths are limited. Using the explant outgrowth technique, Schneider et al. [18] isolated stellate cells from pancreata of rats with cerulein pancreatitis. Bläuer et al. [19] designed a new explant outgrowth system that allowed for the isolation of pancreatic acinar cells at the gasliquid interphase. Carlotti et al. [20] reported that the cell outgrowth from isolated human islets was comprised of adherent fibroblastoid cells that expressed MSC and pericyte markers, as well as nestin and vimentin, but not genes for endocrine hormones. When cultured under appropriate conditions, these cells differentiated into adipocytes and osteoblasts lineages and expressed insulin, glucagons, and somatostatin genes. Several other studies attempting to generate $\beta$-cells from precursor cells from endocrine or exocrine pancreatic explants documented the presence of plastic-adherent mesenchymal cells in cell cultures [21-25]. While early studies suggested that epithelial-to-mesenchymal transition by $\beta$-cells might be responsible for the occurrence of these mesenchymal cells [21], this assumption was recently refuted based on lineage tracing experiments [26-29].

MSCs are multipotent precursor cells for stromal cells, which are capable of differentiating into multiple ectodermal, mesodermal, and endodermal tissues [30]. As such, they have been considered a source of cells for therapeutic approaches for various conditions, including type-1 diabetes. Experimental evidence suggests bone marrow (BM), or adipose tissue-derived MSCs are capable of differentiating into insulin-producing cells in vitro and contribute to the restoration of normoglycemia in animal models of diabetes in vivo $[31,32]$. Human mesenchymal stromal cells that differentiate and mature to hormone-expressing cells in vivo have been referred to as islet-derived precursor cells (IPCs) [33]. Recent evidence suggests MSCs may act as trophic mediators to attenuate $\beta$-cell death and activate endogenous regenerative mechanisms [34-41].

The present study aimed to characterize the mouse pancreas explant cell outgrowth during ex vivo tissue culture. Unlike Carlotti et al. [20] who studied islet outgrowths, we used whole pancreas explants. We reproducibly obtained a population of cells that exhibited a relatively uniform morphology and a stable cell-surface marker profile. The latter was characterized by expression of monocyte/macrophage and hematopoietic markers $(\mathrm{CD} 11 \mathrm{~b}$ and CD45), pericyte/perivascular markers (neuron-glial antigen 2 [NG2] proteoglycan and, to a lesser extent, CD146) [42], and certain MSC and/or endothelial progenitor cell (EPC) markers (CD29 and CD44), but not MSC-defining (CD90 and CD105) and endothelial (CD31) markers. The isolated myelomonocytoid population was propagated for up to 5 passages and was maintained in culture as a monolayer for more than 1 year with no major morphologic or immunophenotypic changes. Plastic-adherent cells spontaneously formed spherical clusters that detached from plastic, which is considered a feature of stemness [43]. They were capable of differentiating along multiple mesenchymal lineages (fat, cartilage, and bone) although this was not demonstrated with single-cell cloning. These findings indicate that pancreas explant cell outgrowths can give rise to a myelomonocytoid population endowed with mesenchymal differentiation potential. These findings are inline with recent data on monocyte-derived mesenchymal progenitors (MOMPs) [44].

\section{Materials and Methods}

2.1. Cell Isolation and Culture. Pancreatic explants were obtained from neonatal (1-2 days of age) male $\mathrm{C} 57 \mathrm{Bl} / 6$ mice (from Charles River Laboratories, France) or C57BL/6$\mathrm{Tg}$ (CAG-EGFP)1Osb/J transgenic mice expressing enhanced green fluorescent protein (EGFP) from an immediate-early CMV promoter (gift of T. Pedrazzini, CHUV, Lausanne). Tissue explants were rinsed abundantly with heparinized saline and then cut into small pieces that were placed in Corning Costar 6-well culture plates (Sigma) with no extracellular matrix (EMC) protein coating. Explants were cultured in MesenCult (MesenCult MSC Basal Medium [Mouse] supplemented with serum-containing MesenCult MSC Stimulatory Supplements [Mouse], both from Stem Cell Technologies). After 2 weeks, tissue explants were removed from the culture plates, while the cell outgrowth was left in place. When adherent cells formed a nearly confluent monolayer, they were detached from plastic with PBS-EDTA, collected, and seeded onto new plates. In separate experiments $(n=2)$, cells were cultured in Dulbecco-modified Eagle medium supplemented with 10\% fetal calf serum (DMEM-10\% FCS), with or without granulocyte-macrophage colonystimulating factor (GM-CSF). In a separate experiment, cells were cultured using a MethoCult (Stem Cell Technologies)based 3D system.

2.2. Flow Cytometric Analyses. For flow cytometric analyses $(n=6)$, cells were gently detached from plastic with PBS-EDTA, filtered through a $70-\mu \mathrm{m}$ filter, centrifuged, and resuspended in reagent A Leucoperm B4FO9B (AbD Serotec) for $15 \mathrm{~min}$ at RT. Then, PBS was added, and cells were centrifuged, resuspended in reagent $\mathrm{B}$, incubated with primary antibody (see Supplementary Table 1 available online at doi: $10.1155 / 2012 / 429868$ ) for $30 \mathrm{~min}$ at RT, and washed with PBS. When needed, cells were resuspended in reagent $B$ and incubated with mouse anti-rat Alexa 488 ( $1: 25$ dilution) for $30 \mathrm{~min}$ at RT. Flow cytometric analyses were performed using a FACSCalibur system (BD Bioscience) and the CellQuest software. Gates used to resolve antigen-expressing cells were set using appropriate isotype-specific control antibodies.

2.3. Immunocytochemistry. Immunocytochemistry was performed as previously described [45]. Briefly, cells were seeded on Lab-Tek Chamber-Slides (Nunc) and fixed with 1\% paraformaldehyde (PFA). For immunostaining of NG2 proteoglycan, a polyclonal rabbit anti-NG2 antibody (Chemicon/Millipore) followed by a goat-anti-rabbit secondary $\mathrm{Ab}$ 


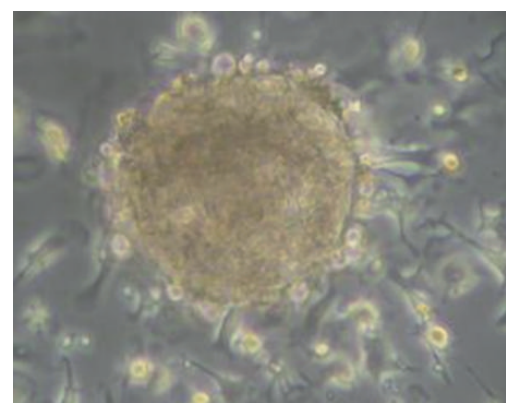

(a)

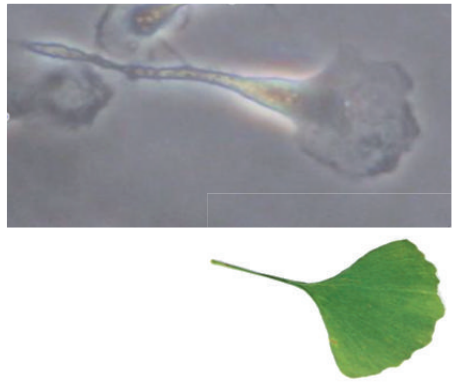

(b)

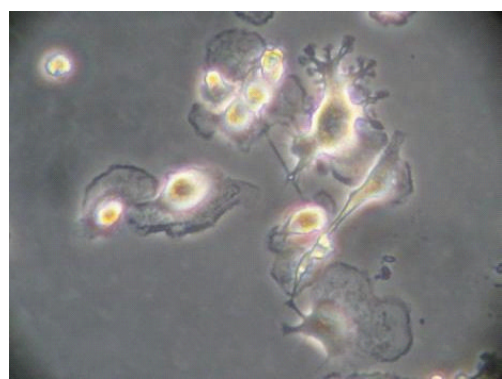

(c)

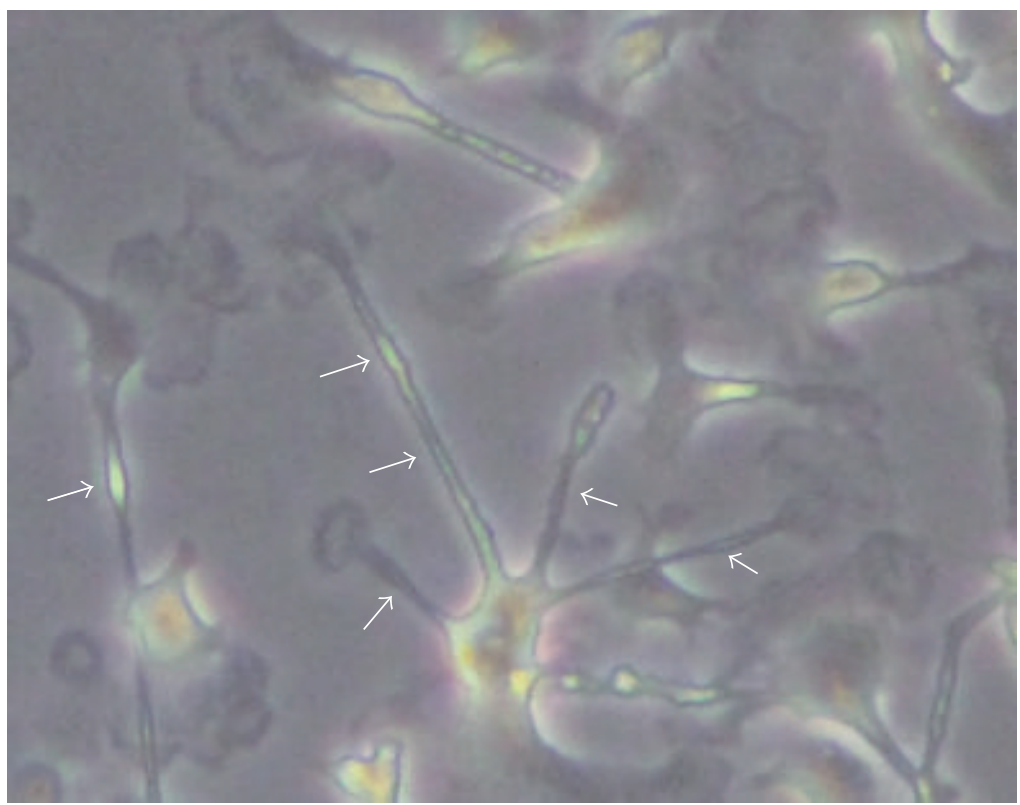

(e)

FIGURE 1: (a) Phase photomicrograph of a pancreatic explant with outgrowing cells in the primary ex vivo tissue culture. (b) High magnification view of an expanded pancreas-derived cell showing a characteristic Gingko biloba leaf-like shape (insert). (c and d) Expanded pancreas-derived cells showing refringent nuclei and thin cytoplasmic processes. (e) Expanded pancreas-derived cells showing a "stellate" pattern of cytoplasmic processes (arrows) with knobs on their extremities.

labeled with Alexa 488 (Invitrogen; 1:400 dilution) was used. Nuclei were stained with DAPI.

2.4. Sphere Formation and Clonogenicity. Free-floating spherical clusters formed spontaneously from monolayers of plastic-adherent cells plated on Corning Costar 6-well plates ( $n=2$ experiments). To assess whether spherical cell clusters were clonally derived, mixtures of pancreatic cell outgrowths from C57BL/6 wildtype (WT) and from C57BL/6-Tg(CAG-EGFP) 1Osb/J transgenic mice were cultured at varying cell ratios. Spheres were analyzed for green fluorescent areas under the fluorescence microscope after 3 weeks ( $n=1$ experiment).

2.5. Differentiation Assays and Cell Staining. To induce adipogenic, osteogenic, and chondrogenic differentiation, pancreatic outgrowth-derived cells were cultured for 3 months in MesenCult and then changed to NH AdipoDiff, OsteoDiff, and ChondroDiff Media (all from Miltenyi), respectively, for 17 days. Adipogenic differentiation was detected by incubating cells with $1 \%$ PFA for $10 \mathrm{~min}$, followed by Oil red-O solution for $15 \mathrm{~min}$, and three PBS washes. Osteogenic differentiation was detected by incubating cells with $1 \%$ PFA for $10 \mathrm{~min}$, followed by $2 \%$ Alizarin red for $5 \mathrm{~min}$, and three PBS washes. Chondrogenic differentiation was detected by staining cells with Alcian-blue. For detection of pancreatic $\beta$ cells, cells cultured in MesenCult supplemented with $1.27 \mu \mathrm{M}$ dexamethasone for 18 days were incubated with 1\% PFA for $10 \mathrm{~min}$, and stained with the zinc-chelating agent, dithizone (Merck) [46-49], for $15 \mathrm{~min}$ according to the manufacturer's instructions.

\section{Results}

3.1. Cell Morphology and Culture. Using the explant outgrowth approach, cells shed by cultured pancreatic explants from neonatal mice were observed on day $3-4$, initially as a 

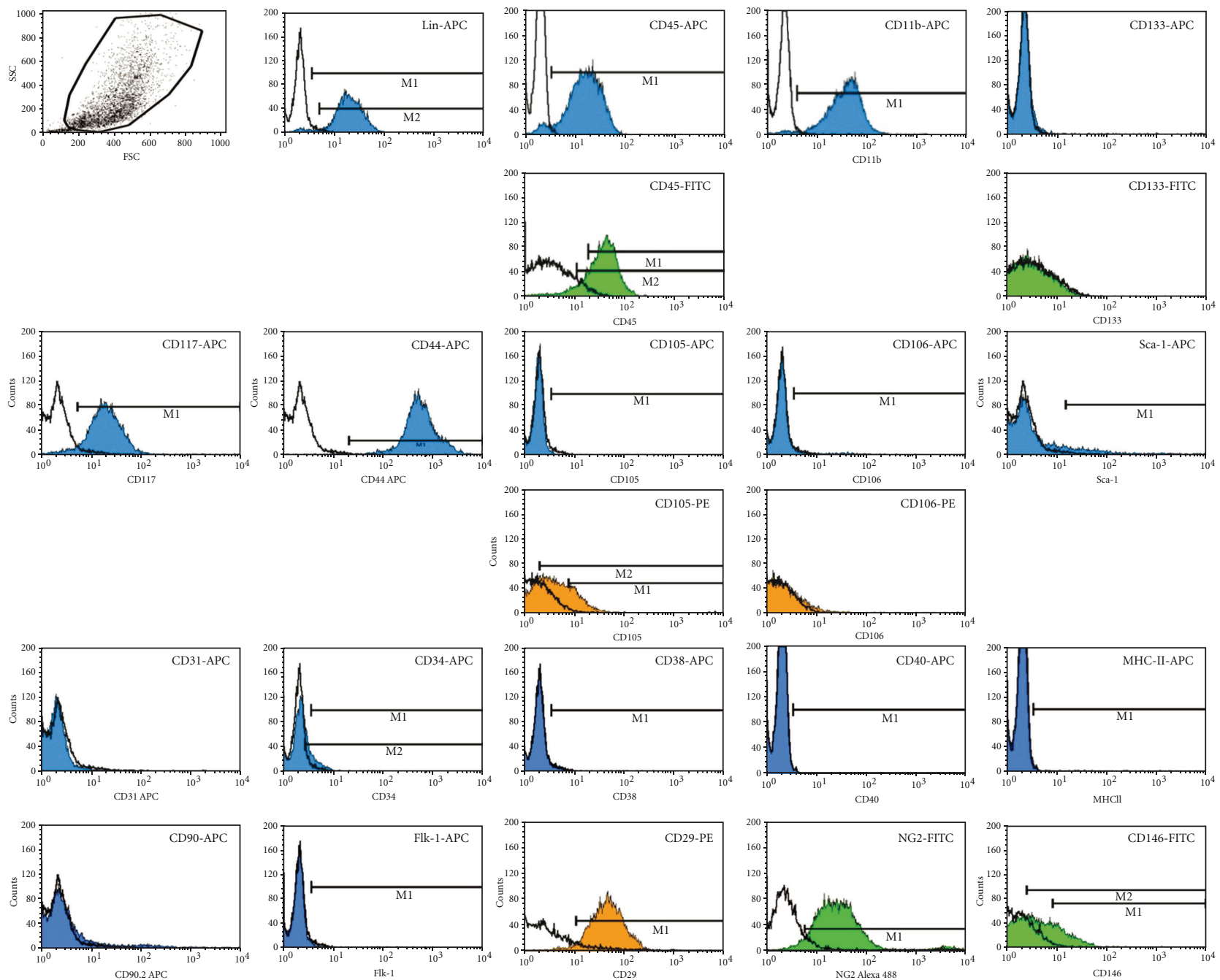

(a)

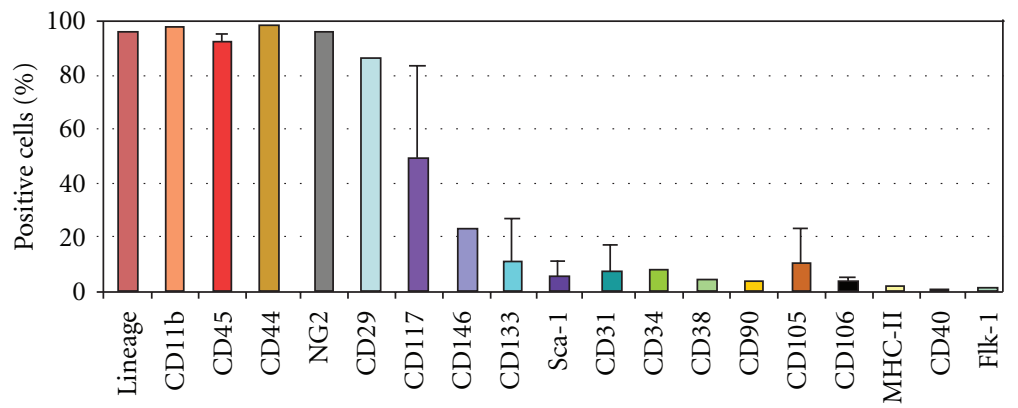

(b)

FIGURE 2: Flow cytometric analyses of the cell-surface marker profile of pancreas outgrowth-derived cells. (a) Representative analysis of cell-surface marker expression of cells cultured 2 months in MesenCult. Blue, green, and orange colors indicate APC, FITC, and PE fluorochromes, respectively. Selected markers (CD45, CD105, CD106, and CD133) were determined with two different fluorochromes. (b) Mean percentages $( \pm S D)$ of cells expressing the indicated cell-surface markers $(n=6$ analyses; $3-5$ samples for each marker, excepted for a subset of markers [NG2, CD29, CD146, CD34, CD38, MHC-II, CD40, and Flk-1] for which a single measure is available).

heterogeneous population of plastic-adherent cells showing both spindle-shaped and round morphologies (Figure 1(a)). After 4-6 weeks, cells acquired a relatively uniform morphology characterized by one or multiple thin cytoplasmic processes carrying a knob on their extremities (this distinctive cell morphology resembled a gingko biloba leaf; Figures $1(\mathrm{~b})$ and $1(\mathrm{~d}))$. Cells with multiple thin processes exhibited a stellate shape, whereby processes from neighboring cells 


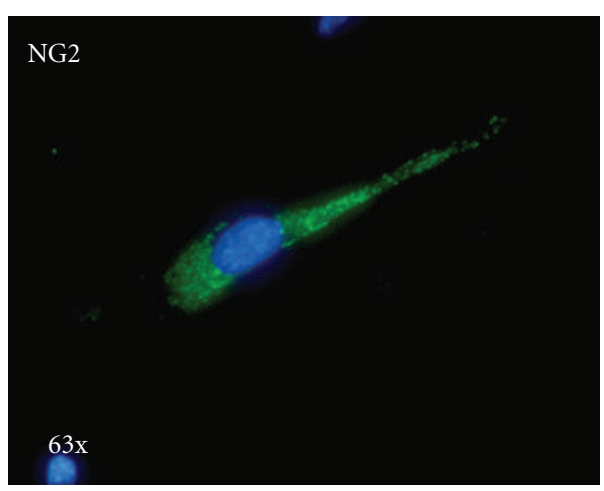

(a)

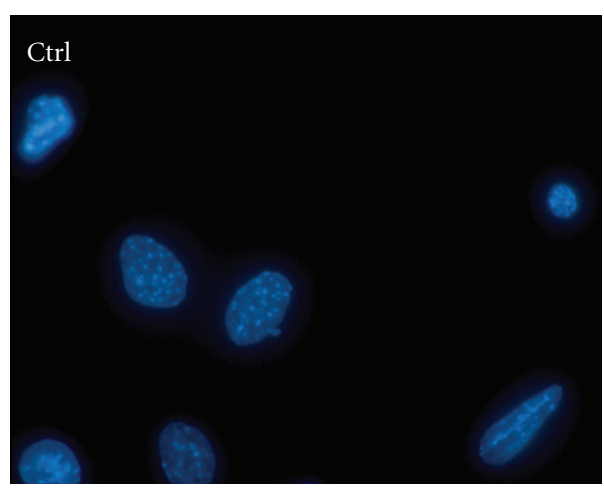

(b)

FIGURE 3: NG2 expression by pancreas outgrowth-derived cells. (a) NG2 immunostaining using an Alexa 488-labeled secondary antibody (green); nuclear staining with DAPI (blue). (b) Control (secondary antibody only).

appeared to establish inter-cellular contacts (Figure 1(e)). Cells grew slowly and were propagated for up to 5 passages. They could be maintained in culture for more than 1 year.

3.2. Cell-Surface Marker Profile. Cells cultured for 2 months in MesenCult were analyzed by flow cytometry. They expressed lineage (Lin) differentiation antigens, the common leukocyte antigen CD45, the monocytic marker CD11b, the hematopoietic marker c-kit (CD117), the pericyte/mesoangioblast markers NG2 proteoglycan, and CD146 [24], CD44 (a receptor for hyaluronic acid considered a MSC and EPC marker), and CD29 (integrin $\beta 1 /$ fibronectin receptor; Figure 2). NG2 expression was demonstrated immunocytochemically (Figure 3). Stem cell antigen-1 (Sca-1), CD34 (an hematopoietic and EPC marker), CD133 (a stem cell marker), CD31 (an endothelial marker), CD90 (THY1 Tcell antigen; a MSC marker), and CD105 (endoglin; a MSC marker) were expressed by small cell subsets. CD38, CD40, Flk-1, and major histocompatibility complex (MHC) class II molecules were not expressed. In cells cultured in MesenCult for 2 months and then changed to DMEM-10\% FCS for 3 weeks, $\mathrm{CD}_{4} 5^{+}, \mathrm{CD} 11 \mathrm{~b}{ }^{+}$, or c-kit ${ }^{+}$subsets were reduced by approximately half compared with cells maintained in MesenCult (Figure 4). Cell culturing in DMEM-10\% FCS supplemented with GM-CSF did not alter CD45, CD11b, and c-kit expression (data not shown).

3.3. Nonclonal Sphere Formation. The isolated population formed spherical clusters that detached from plastic and floated free in the medium. Spheres collected and plated onto new plates disaggregated and gave rise to a monolayer of sphere-derived cells, which were able to form a second generation of spheres. This procedure could be repeated for 3 cycles, at least. We tested the clonality of first-generation spheres by culturing mixtures of cells derived from GFP transgenic and WT mice. While spheres formed by GFP cells were entirely green fluorescent, and those formed by WT cells were non-fluorescent, those formed by mixtures of GFP and WT cells included both green fluorescent and nonfluorescent areas (Figure 5), indicating nonclonality.
3.4. 3D-Cell Culture System in MethoCult. Cells placed in a 3D-culture MethoCult system formed long, dendritic-like filaments after 4 to 8 days in culture (Figure 6).

3.5. Cell Differentiation Potential. Under appropriate conditions, pancreas outgrowth-derived cells differentiated along osteogenic, chondrogenic, and adipogenic lineages, as evidenced by Alizarin-red (Figure 7(a)), Alcian-blue (Figure $7(\mathrm{~b})$ ), and oil red-O staining (Figures $7(\mathrm{c})$ and $7(\mathrm{~d})$ ), respectively. Dithizone staining was positive for a subset of cells cultured in $1.27 \mu \mathrm{M}$ dexamethasone/MesenCult for 18 days (Figures $7(\mathrm{e})$ and $7(\mathrm{f})$ ).

\section{Discussion}

The main finding of the present study is that cells obtained by outgrowth from murine pancreas explants in MesenCult give rise to a population of myelomonocytoid cells endowed with mesenchymal differentiation potential. These cells also stain positive with dithizone, a zinc-chelating agent commonly used to detect insulin-producing cells [46-49]. The endocrine differentiation potential of these cells is being addressed in an ongoing study. In the present study, we focus on their phenotype and MSC-like characteristics.

Monocyte-derived cells include macrophages, fibrocytes, dendritic cells, osteoclasts, and adipocytes. Monocytes, unlike macrophages and fibrocytes, do not express CD105 [50-52]. Because the isolated population lacks CD105 expression, it appears to have a monocytoid phenotype. This population meets only part of the minimal criteria for defining MSC established by the International Society for Cellular Therapy [53]: plastic-adherence in standard culture conditions and capacity to differentiate into osteoblasts, adipocytes, and chondroblasts in vitro (in the present study, multilineage differentiation potential was not demonstrated with single-cell cloning). Regarding the cell-surface marker profile, the minimal criteria for defining MSC, namely, expression of CD105 and CD90 but not CD45, are not met. However, other MSC/stromal markers (CD44 and CD29) and pericyte/perivascular markers (NG2 and CD146) are 


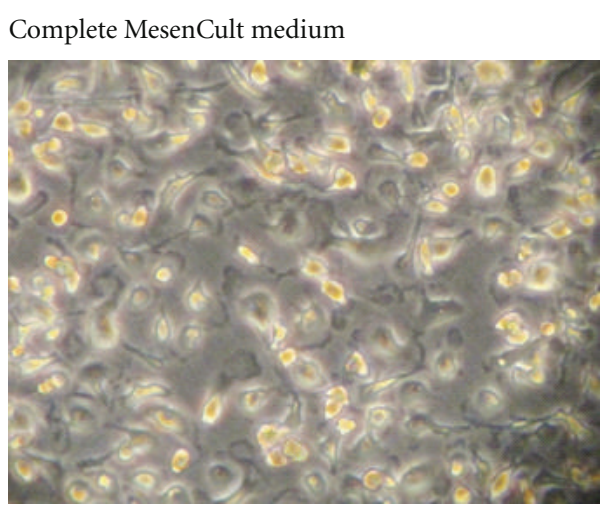

(a)
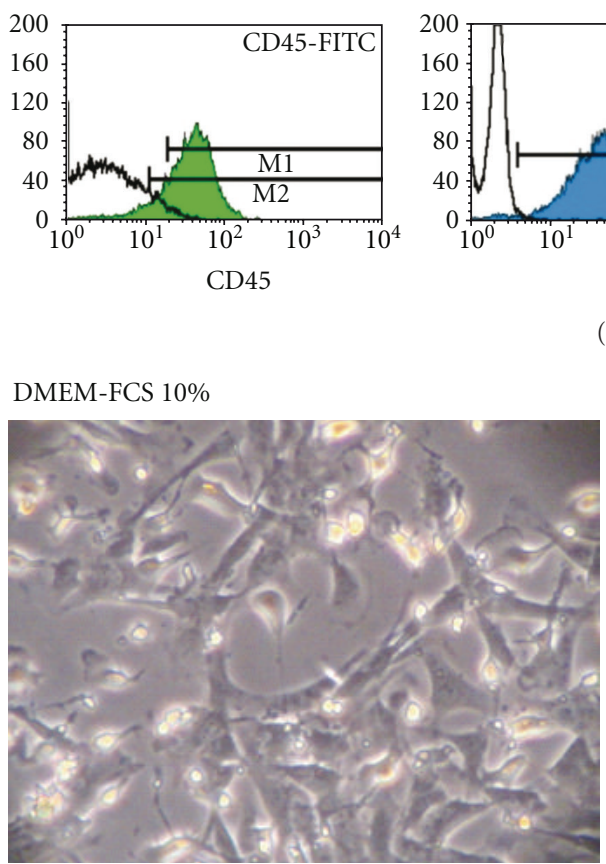

(d)

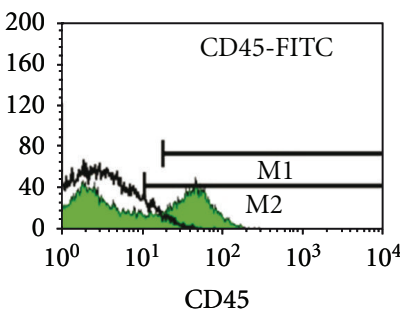

DMEM-FCS $10 \%$

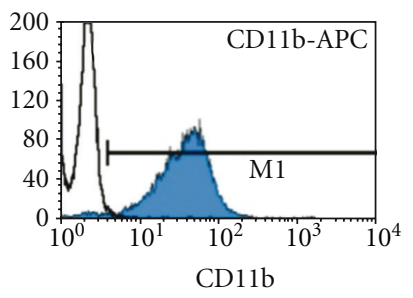

(c)

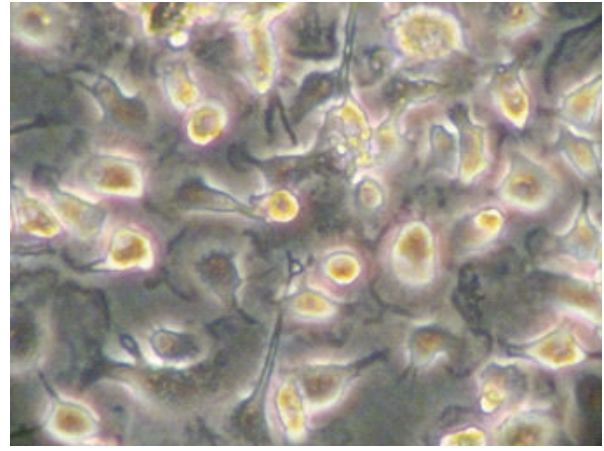

(b)

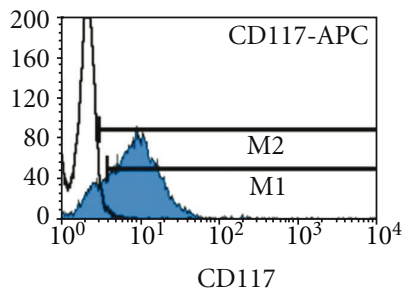

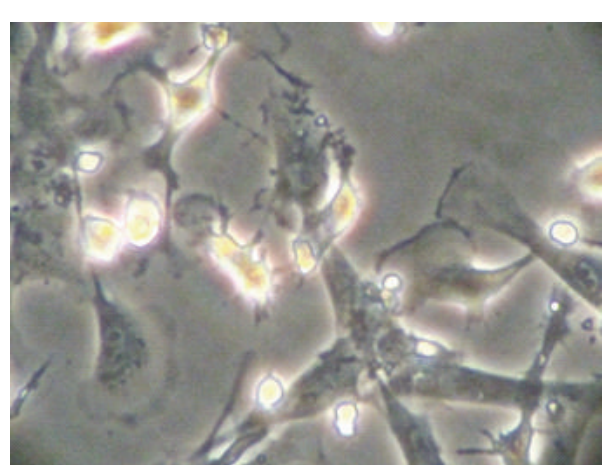

(e)
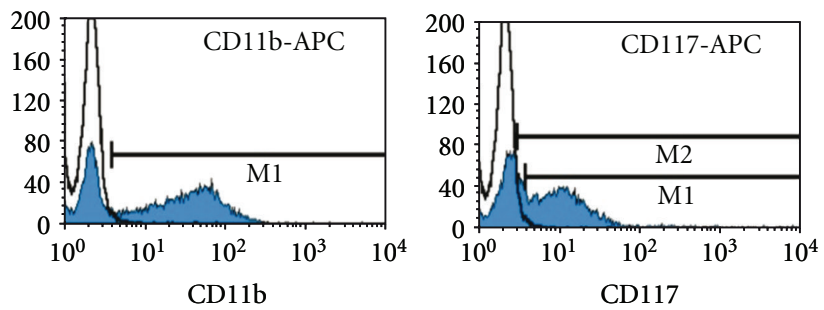

(f)

FIGURE 4: Effects of the culture medium on cell morphology and antigen expression. (a-c) Cells cultured in MesenCult for 1 month display highly refringent nuclei, gingko biloba leaf-like shapes, and CD45, CD11b, and CD117 expression. (d-f) Cells initially derived in MesenCult

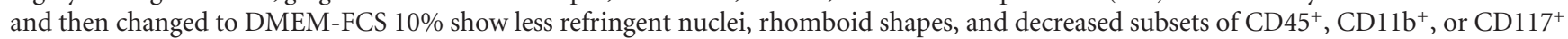
cells.

expressed [42]. In this regard, it has been shown that human MSCs in several organs originate from pericytes/perivascular cells and express NG2 [54]. For comparison, previous studies have shown that human islet outgrowths are positive for multiple MSC and pericyte markers $\left(\mathrm{CD} 105^{+}, \mathrm{CD} 90^{+}\right.$, $\mathrm{CD} 44^{+}, \mathrm{CD} 29^{+}, \mathrm{NG}^{+}$, and $\mathrm{CD} 146^{+}$) but negative for CD45.

Pancreas-derived cells cultured in the 3D-MethoCult system exhibit a dendritic or oligodendrocytic-like morphology 

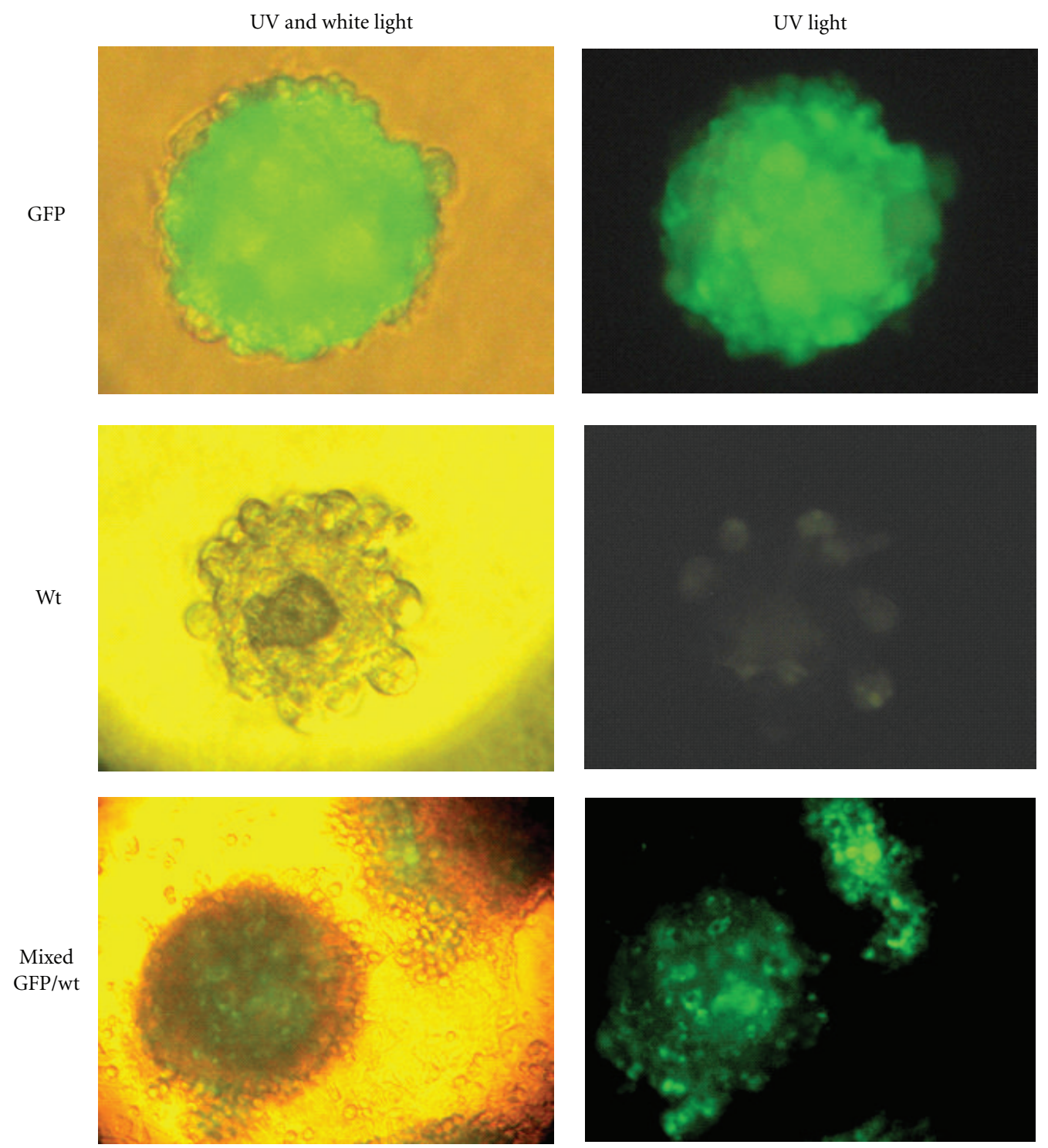

FIGURE 5: Photomicrographs and UV photomicrographs of sphere clusters formed by pancreas outgrowth-derived cells from either WT or GFP-transgenic mice, or by mixtures of the two. The latter show a patchy white/green pattern under the UV light, indicating that spheres are nonclonal.

characterized by multiple branched filaments. Microglia have a $\mathrm{CD} 11 \mathrm{~b}^{+} \mathrm{CD} 45^{\text {lo }}$ phenotype and can be distinguished from primary macrophages on the basis of their CD45 expression level [55]. Differentiation of mouse BM-derived stem cells toward microglia-like cells has been reported [56].

The isolated myelomonocytoid population appears to have an advantage in terms of survival or growth compared with other cells present in the cellular outgrowth from pancreatic explants. These cells may die off and be taken over by the myelomonocytoid component that persists after extended periods of time. The underlying mechanism is unclear. Because MesenCult is a commercially available medium that has been optimized for growth of MSC, the emergence of a myelomonocytoid population over time is somewhat surprising. In a previous study [15], we used this medium to expand mouse cardiac-derived MSC, which displayed a stable phenotype $\left(\mathrm{Lin}^{-}, \mathrm{Sca}-1^{+}, \mathrm{CD} 0^{+}\right.$, $\mathrm{CD}_{105^{+}}, \mathrm{CD} 45^{-}$, and $\mathrm{CD} 31^{-}$) for more than 25 passages. This observation indicates that MesenCult can preserve the phenotype of cultured MSC for extended periods of time, at least under certain circumstances.

The mesenchymal differentiation potential of the myelomonocytoid population may appear at odds with the established CD45- MSC phenotype [53]. However, Sordi et al. [41] recently showed that mesenchymal cells emerging from human pancreatic culture did not result from an epithelial to mesenchymal transition but represented the expansion of a pool of resident MSC located in the periacinar, perivascular, and periductal space. Using a $\mathrm{GFP}^{+}$ BM transplant model, they showed that mesenchymal cells emerging from pancreatic endocrine or exocrine tissue culture originated mainly from the $\mathrm{CD} 45^{+} \mathrm{BM}$ compartment. 


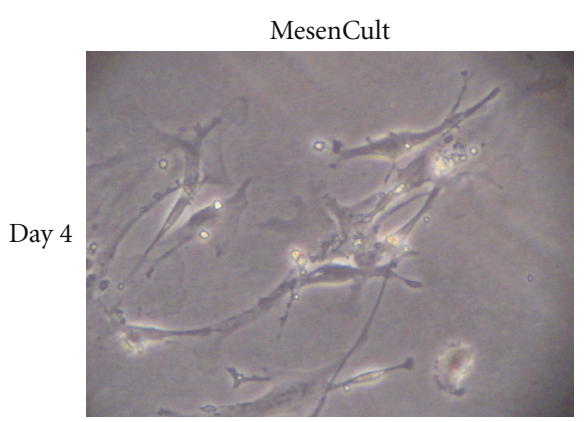

(a)

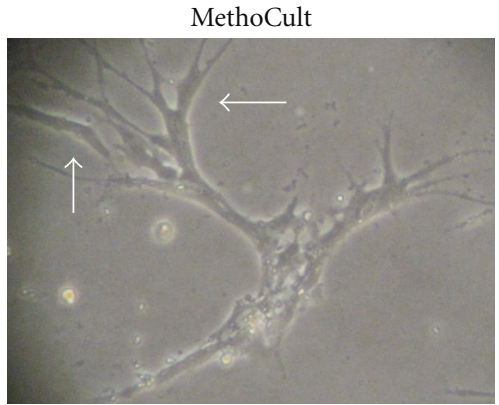

(b)

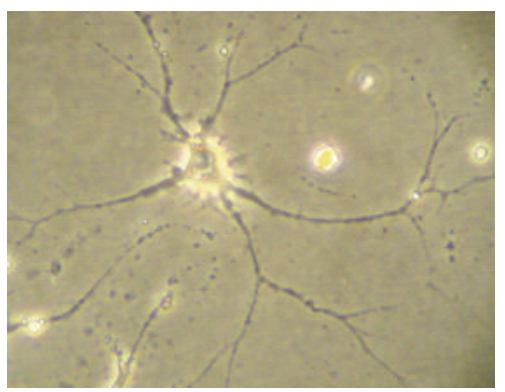

(c)

FIGURE 6: Pancreas-derived cells ( 5 weeks after plating; passage 3) were seeded at very low density ( $10^{3}$ cells/35 mm plate) in either MesenCult (a) or MethoCult (b and c). Pictures were taken 4-8 days later. Thin dendritic-like cell extensions, or filaments, were seen in MethoCult (c), but not in MesenCult (not shown).

Athough these cells expressed negligible levels of islet-specific genes, they improved islet function and neovascularization after transplantation with a minimal islet mass in a mouse model. Kaiser et al. [57] showed that a small population of $\mathrm{BM}$ MSC originated from the $\mathrm{CD} 45^{+} \mathrm{CD} 34^{+}$fraction, whereas the majority was obtained from the $\mathrm{CD} 45^{-} \mathrm{CD} 34^{-}$ fraction. MSC from either fraction could be differentiated into adipocytes, osteocytes, and chondroblasts. Additional studies confirmed that MSC can express CD45 under certain conditions [58-60]. In some cases, CD45 expression was dramatically downregulated during in vitro culture [57, 58]. As mentioned above, our data suggest that MesenCult may preserve CD45 expression in cultured pancreas-derived myelomonocytoid cells, whereas partial downregulation of CD45 expression was observed in a standard culture medium (DMEM-10\% FCS).

Pancreas-derived myelomonocytoid cells form spherical clusters, which is considered a feature of stemness [43]. However, these spheres are nonclonal. Similar findings have been reported for neural stem cells, as colonies formed by these cells can grow clonal or nonclonal [61].

The origin of the isolated myelomonocytoid population remains unclear. It might originate from blood monocytes trapped in the intravascular compartment of tissue explants, as recently shown for $\mathrm{CD}_{4} 5^{+}$cells from cardiac explant outgrowths [62]. It should be mentioned, however, that we were not able to isolate myelomonocytoid cells from murine BM-derived cells using the same culture conditions. Alternatively, this population might originate from pancreasresident monocytes, monocyte-derived cells, or MSC. In this regard, Freisinger et al. [63] showed that clonally isolated, adipose-derived MSC cultured in appropriate differentiation media gave rise to cells expressing monocyte/macrophage and early hematopoietic markers.

Our findings are in general agreement with recent reports on multipotent monocytes. Zhao et al. [64] isolated a subset of adult pluripotent stem cells $\left(\mathrm{CD} 14^{+}, \mathrm{CD} 34^{+}\right.$, and $\mathrm{CD}_{4} 5^{+}$) from human peripheral blood monocytes. These cells in appearance resembled fibroblasts, expanded in the presence of macrophage colony-stimulating factor (M-CSF), and could be differentiated into mature macrophages and $\mathrm{T}$ lymphocytes, as well as into epithelial, endothelial, neuronal, and liver cells in the presence of appropriate growth factors. Kuwana et al. [44] and Kuwana and Seta [65] described human blood monocyte-derived multipotent cells (MOMCs; $\mathrm{CD}_{14}{ }^{+}, \mathrm{CD}_{3} 4^{+}, \mathrm{CD} 45^{+}$, and type-I collagen ${ }^{+}$) that exhibited a fibroblast-like morphology and contained progenitors with the capacity to differentiate into bone, cartilage, fat, skeletal muscle, cardiac muscle, neuron, and endothelium [65-67]. Romagnani et al. [68] described circulating clonogenic, multipotent $\mathrm{CD} 14^{+} \mathrm{CD} 34^{\text {lo }}$ cells that proliferated in response to stem cell growth factors. Ungefroren and Fändrich [69] reported that the programmable cell of monocytic origin (PCMO) is a potential adult stem/progenitor cell source for the generation of islet cells. Hur et al. [48] recently showed that human peripheral blood monocytes could be differentiated into insulin-producing cells using the hematosphere culture technique. Collectively, these data suggest that blood monocytes and monocyte-derived cells, although not considered classic adult stem cells, may represent versatile progenitor cells capable of generating multiple types of cells. 


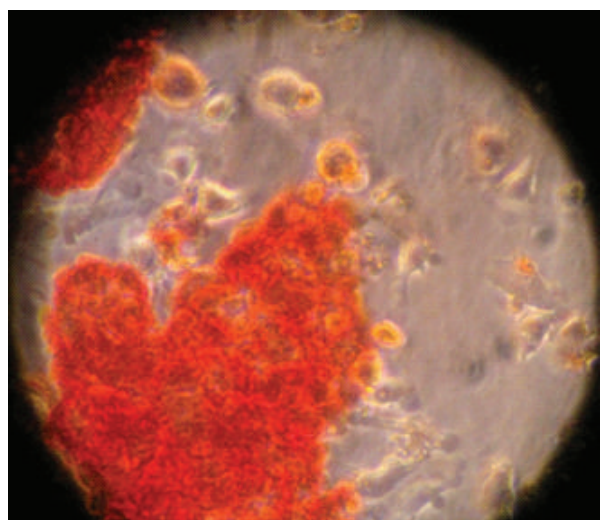

(a)

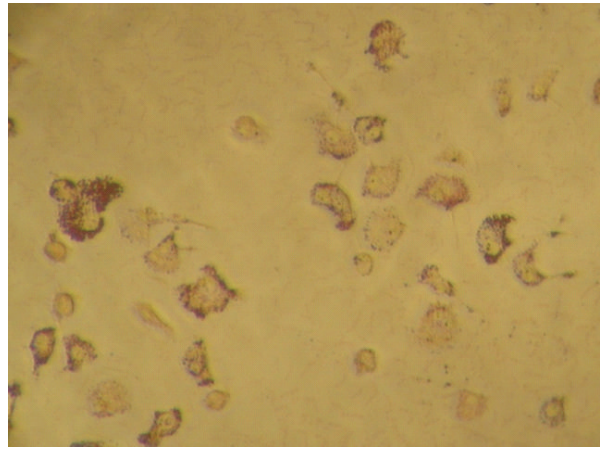

(c)

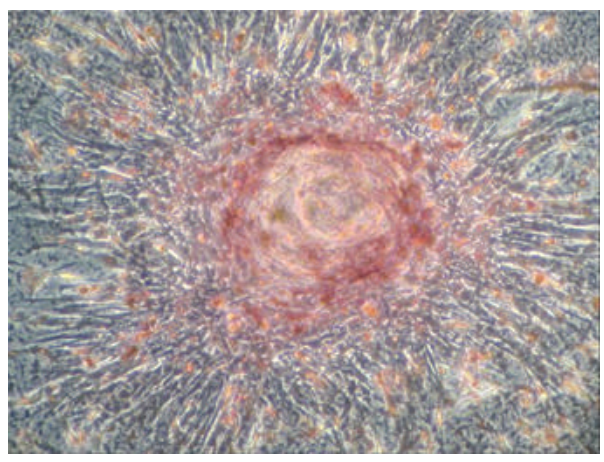

(e)

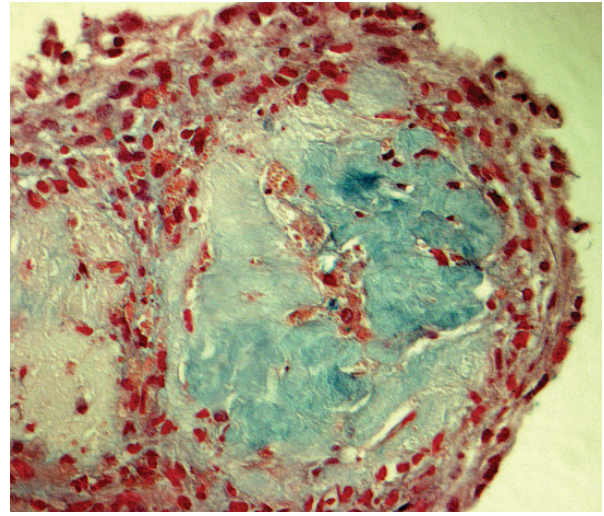

(b)

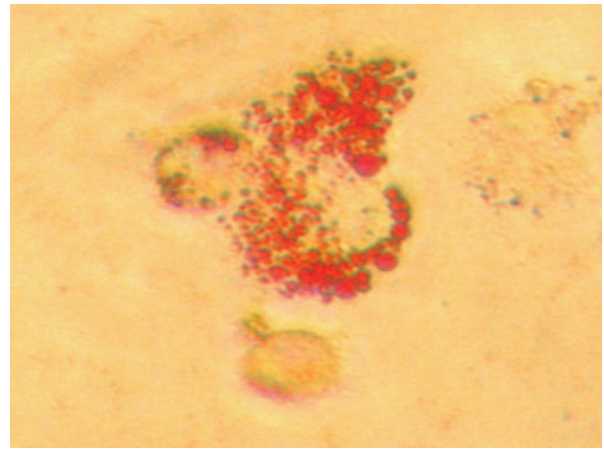

(d)

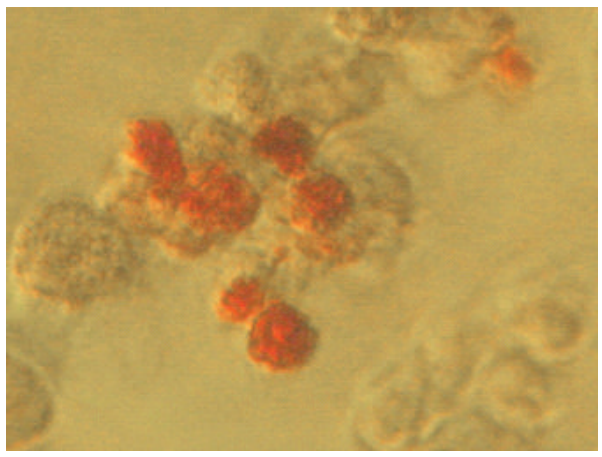

(f)

Figure 7: Multilineage differentiation of pancreas-derived cells. (a) Osteogenic differentiation (Alizarin-red staining). (b) Chondrogenic differentiation (Alcian-blue staining). (c and d) Adipogenic differentiation (Oil red-O staining; low/high magnification views). (e and f) Cells cultured for 2 months in MesenCult showed areas of positive staining with dithizone (red) as evidence of zinc-rich insulin-producing cells (low/high magnification views).

Owing to their mesenchymal differentiation potential, pancreas outgrowth-derived myelomonocytoid cells are of potential interest to cell therapy applications even though this aspect was not directly addressed by the present study. Sordi et al. [41] reported beneficial effects of pancreatic MSC in diabetic mice, as mentioned above. When cotransplanted with a minimal islet mass, these cells improved neovascularization and islet function. This effect was not due to MSC differentiation into insulin-secreting cells, but to MSCmediated protective effects on transplanted islets. Moreover, Johansson et al. [70] showed that MSC within composite endothelial cell-MSC-pancreatic islets improved endothelial cell proliferation and sprouting in vitro. It therefore could be speculated that pancreas-derived myelomonocytoid cells endowed with MSC potential might exert trophic effects on pancreatic islets via paracrine mechanisms, as reported for pancreatic MSC by Sordi et al. [41]. Further studies are warranted to test this hypothesis and to define the origin and the endocrine potential of the pancreas-derived myelomonocytoid population.

\section{Acknowledgments}

Support by the Fondation Vaudoise de Cardiologie (Lausanne, Switzerland), the Cecilia Augusta Foundation, the METIS Foundation Sergio Mantegazza, the "Fondazione per 
la ricerca sulla trasfusione e sui trapianti” (Lugano, Switzerland), and the Swiss Heart Foundation (Berne, Switzerland) is gratefully acknowledged.

\section{References}

[1] J. Domínguez-Bendala, L. Inverardi, and C. Ricordi, "Regeneration of pancreatic beta-cell mass for the treatment of diabetes," Expert Opinion on Biological Therapy, vol. 12, no. 6, pp. 731-741, 2012.

[2] T. Guo and M. Hebrok, "Stem cells to pancreatic $\beta$-cells: new sources for diabetes cell therapy," Endocrine Reviews, vol. 30, no. 3, pp. 214-227, 2009.

[3] Y. Dor, J. Brown, O. I. Martinez, and D. A. Melton, "Adult pancreatic $\beta$-cells are formed by self-duplication rather than stem-cell differentiation," Nature, vol. 429, no. 6987, pp. 4146, 2004.

[4] S. Bonner-Weir, M. Taneja, G. C. Weir et al., "In vitro cultivation of human islets from expanded ductal tissue," Proceedings of the National Academy of Sciences of the United States of America, vol. 97, no. 14, pp. 7999-8004, 2000.

[5] M. Reichert and A. K. Rustgi, "Pancreatic ductal cells in development, regeneration, and neoplasia," The Journal of Clinical Investigation, vol. 121, pp. 4572-4578, 2011.

[6] X. Xu, J. D’Hoker, G. Stangé et al., “ $\beta$ cells can be generated from endogenous progenitors in injured adult mouse pancreas," Cell, vol. 132, no. 2, pp. 197-207, 2008.

[7] V. K. Ramiya, M. Maraist, K. E. Arfors, D. A. Schatz, A. B. Peck, and J. G. Cornelius, "Reversal of insulin-dependent diabetes using islets generated in vitro from pancreatic stem cells," Nature Medicine, vol. 6, no. 3, pp. 278-282, 2000.

[8] R. M. Seaberg, S. R. Smukler, T. J. Kieffer et al., "Clonal identification of multipotent precursors from adult mouse pancreas that generate neural and pancreatic lineages," Nature Biotechnology, vol. 22, no. 9, pp. 1115-1124, 2004.

[9] R. M. Baertschiger, D. Bosco, P. Morel et al., "Mesenchymal stem cells derived from human exocrine pancreas express transcription factors implicated in beta-cell development," Pancreas, vol. 37, no. 1, pp. 75-84, 2008.

[10] V. M. Schwitzgebel, D. W. Scheel, J. R. Conners et al., "Expression of neurogenin3 reveals an islet cell precursor population in the pancreas," Development, vol. 127, no. 16, pp. 3533-3542, 2000.

[11] H. T. Lin, S. H. Chiou, C. L. Kao et al., "Characterization of pancreatic stem cells derived from adult human pancreas ducts by fluorescence activated cell sorting," World Journal of Gastroenterology, vol. 12, no. 28, pp. 4529-4535, 2006.

[12] Y. Oshima, A. Suzuki, K. Kawashimo, M. Ishikawa, N. Ohkohchi, and H. Taniguchi, "Isolation of mouse pancreatic ductal progenitor cells expressing CD133 and c-Met by flow cytometric cell sorting," Gastroenterology, vol. 132, no. 2, pp. 720-732, 2007.

[13] A. Suzuki, H. Nakauchi, and H. Taniguchi, "Prospective isolation of multipotent pancreatic progenitors using flowcytometric cell sorting," Diabetes, vol. 53, no. 8, pp. 2143 2152, 2004.

[14] T. Sugiyama, R. T. Rodriguez, G. W. McLean, and S. K. Kim, "Conserved markers of fetal pancreatic epithelium permit prospective isolation of islet progenitor cells by FACS," Proceedings of the National Academy of Sciences of the United States of America, vol. 104, no. 1, pp. 175-180, 2007.
[15] H. Immervoll, D. Hoem, P. Ø Sakariassen, O. J. Steffensen, and A. Molven, "Expression of the "stem cell marker" CD133 in pancreas and pancreatic ductal adenocarcinomas," $B M C$ Cancer, vol. 8, article 48, 2008.

[16] Y. C. Ya-Chieh Hsu and E. Fuchs, "A family business: stem cell progeny join the niche to regulate homeostasis," Nature Reviews Molecular Cell Biology, vol. 13, pp. 103-114, 2012.

[17] F. Esni, Y. Miyamoto, S. D. Leach, and B. Ghosh, "Primary explant cultures of adult and embryonic pancreas," Methods in Molecular Medicine, vol. 103, pp. 259-271, 2005.

[18] E. Schneider, A. Schmid-Kotsas, J. Zhao et al., "Identification of mediators stimulating proliferation and matrix synthesis of rat pancreatic stellate cells," American Journal of Physiology, vol. 281, no. 2, pp. C532-C543, 2001.

[19] M. Bläuer, I. Nordback, J. Sand, and J. Laukkarinen, "A novel explant outgrowth culture model for mouse pancreatic acinar cells with long-term maintenance of secretory phenotype," European Journal of Cell Biology, vol. 90, pp. 1052-1160, 2011.

[20] F. Carlotti, A. Zaldumbide, C. J. Loomans et al., "Isolated human islets contain a distinct population of mesenchymal stem cells," Islets, vol. 2, no. 3, pp. 164-173, 2010.

[21] M. C. Gershengorn, A. A. Hardikar, C. Wei, E. CerasRaaka, B. Marcus-Samuels, and B. M. Raaka, "Epithelial-tomesenchymal transition generates proliferative human islet precursor cells," Science, vol. 306, no. 5705, pp. 2261-2264, 2004.

[22] A. Lechner, A. L. Nolan, R. A. Blacken, and J. F. Habener, "Redifferentiation of insulin-secreting cells after in vitro expansion of adult human pancreatic islet tissue," Biochemical and Biophysical Research Communications, vol. 327, no. 2, pp. 581-588, 2005.

[23] L. Ouziel-Yahalom, M. Zalzman, L. Anker-Kitai et al., "Expansion and redifferentiation of adult human pancreatic islet cells," Biochemical and Biophysical Research Communications, vol. 341, no. 2, pp. 291-298, 2006.

[24] M. Eberhardt, P. Salmon, M. A. von Mach et al., "Multipotential nestin and Isl-1 positive mesenchymal stem cells isolated from human pancreatic islets," Biochemical and Biophysical Research Communications, vol. 345, no. 3, pp. 1167-1176, 2006.

[25] R. Gallo, F. Gambelli, B. Gava et al., "Generation and expansion of multipotent mesenchymal progenitor cells from cultured human pancreatic islets," Cell Death and Differentiation, vol. 14, no. 11, pp. 1860-1871, 2007.

[26] R. A. Morton, E. Geras-Raaka, L. M. Wilson, B. M. Raaka, and M. C. Gershengorn, "Endocrine precursor cells from mouse islets are not generated by epithelial-to-mesenchymal transition of mature beta cells," Molecular and Cellular Endocrinology, vol. 270, no. 1-2, pp. 87-93, 2007.

[27] F. Atouf, H. P. Cheol, K. Pechhold, M. Ta, Y. Choi, and N. L. Lumelsky, "No evidence for mouse pancreatic $\beta$-cell epithelialmesenchymal transition in vitro," Diabetes, vol. 56, no. 3, pp. 699-702, 2007.

[28] L. G. Chase, F. Ulloa-Montoya, B. L. Kidder, and C. M. Verfaillie, "Islet-derived fibroblast-like cells are not derived via epithelial-mesenchymal transition from Pdx-1 or insulinpositive cells," Diabetes, vol. 56, no. 1, pp. 3-7, 2007.

[29] H. A. Russ, Y. Bar, P. Ravassard, and S. Efrat, "In vitro proliferation of cells derived from adult human $\beta$-cells revealed by cell-lineage tracing," Diabetes, vol. 57, no. 6, pp. 1575-1583, 2008.

[30] D. S. Krause, N. D. Theise, M. I. Collector et al., "Multi-organ, multi-lineage engraftment by a single bone marrow-derived stem cell," Cell, vol. 105, no. 3, pp. 369-377, 2001. 
[31] C. Moriscot, F. de Fraipont, M. J. Richard et al., "Human bone marrow mesenchymal stem cells can express insulin and key transcription factors of the endocrine pancreas developmental pathway upon genetic and/or microenvironmental manipulation in vitro," Stem Cells, vol. 23, no. 4, pp. 594-603, 2005.

[32] K. Timper, D. Seboek, M. Eberhardt et al., "Human adipose tissue-derived mesenchymal stem cells differentiate into insulin, somatostatin, and glucagon expressing cells," Biochemical and Biophysical Research Communications, vol. 341, no. 4, pp. 1135-1140, 2006.

[33] B. Davani, L. Ikonomou, B. M. Raaka et al., "Human isletderived precursor cells are mesenchymal stromal cells that differentiate and mature to hormone-expressing cells in vivo," Stem Cells, vol. 25, no. 12, pp. 3215-3222, 2007.

[34] A. Ianus, G. G. Holz, N. D. Theise, and M. A. Hussain, "In vivo derivation of glucose-competent pancreatic endocrine cells from bone marrow without evidence of cell fusion," The Journal of Clinical Investigation, vol. 111, no. 6, pp. 843-850, 2003.

[35] A. Lechner, Y. G. Yang, R. A. Blacken, L. Wang, A. L. Nolan, and J. F. Habener, "No evidence for significant transdifferentiation of bone marrow into pancreatic beta-cells in vivo," Diabetes, vol. 53, no. 3, pp. 616-623, 2004.

[36] A. I. Caplan and J. E. Dennis, "Mesenchymal stem cells as trophic mediators," Journal of Cellular Biochemistry, vol. 98, no. 5, pp. 1076-1084, 2006.

[37] R. H. Lee, M. J. Seo, R. L. Reger et al., "Multipotent stromal cells from human marrow home to and promote repair of pancreatic islets and renal glomeruli in diabetic NOD/scid mice," Proceedings of the National Academy of Sciences of the United States of America, vol. 103, no. 46, pp. 17438-17443, 2006.

[38] V. S. Urbán, J. Kiss, J. Kovács et al., "Mesenchymal stem cells cooperate with bone marrow cells in therapy of diabetes," Stem Cells, vol. 26, no. 1, pp. 244-253, 2008.

[39] E. J. Estrada, F. Valacchi, E. Nicora et al., "Combined treatment of intrapancreatic autologous bone marrow stem cells and hyperbaric oxygen in type 2 diabetes mellitus," Cell Transplantation, vol. 17, no. 12, pp. 1295-1304, 2008.

[40] M. Zhao, S. A. Amiel, S. Ajami et al., "Amelioration of streptozotocin-induced diabetes in mice with cells derived from human marrow stromal cells," PLoS ONE, vol. 3, no. 7, Article ID e2666, 2008.

[41] V. Sordi, R. Melzi, A. Mercalli et al., "Mesenchymal cells appearing in pancreatic tissue culture are bone marrowderived stem cells with the capacity to improve transplanted islet function," Stem Cells, vol. 28, no. 1, pp. 140-151, 2010.

[42] C. L. Maier, B. R. Shepherd, T. Yi, and J. S. Pober, "Explant outgrowth, propagation and characterization of human pericytes," Microcirculation, vol. 17, no. 5, pp. 367-380, 2010.

[43] E. Pastrana, V. Silva-Vargas, and F. Doetsch, "Eyes wide open: a critical review of sphere-formation as an assay for stem cells," Cell Stem Cell, vol. 8, no. 5, pp. 486-498, 2011.

[44] M. Kuwana, Y. Okazaki, H. Kodama et al., "Human circulating $\mathrm{CD} 14^{+}$monocytes as a source of progenitors that exhibit mesenchymal cell differentiation," Journal of Leukocyte Biology, vol. 74, no. 5, pp. 833-845, 2003.

[45] A. Meinhardt, A. Spicher, M. E. Roehrich, I. Glauche, P. Vogt, and G. Vassalli, "Immunohistochemical and flow cytometric analysis of long-term label-retaining cells in the adult heart," Stem Cells and Development, vol. 20, no. 2, pp. 211-222, 2011.

[46] Z. A. Latif, J. Noel, and R. Alejandro, "A simple method of staining fesh and cultured islets," Transplantation, vol. 45, no. 4, pp. 827-830, 1988.
[47] A. Shiroi, M. Yoshikawa, H. Yokota et al., "Identification of insulin-producing cells derived from embryonic stem cells by zinc-chelating dithizone," Stem Cells, vol. 20, no. 4, pp. 284$292,2002$.

[48] J. Hur, J. M. Yang, J. I. Choi et al., "New method to differentiate human peripheral blood monocytes into insulin producing cells: human hematosphere culture," Biochemical and Biophysical Research Communications, vol. 418, pp. 765769, 2012.

[49] A. Rezania, M. J. Riedel, R. D. Wideman et al., "Production of functional glucagon-secreting $\alpha$-cells from human embryonic stem cells," Diabetes, vol. 60, no. 1, pp. 239-247, 2011.

[50] W. Gorczyca, Z. Y. Sun, W. Cronin, X. Li, S. Mau, and S. Tugulea, "Immunophenotypic pattern of myeloid populations by flow cytometry analysis," Methods in Cell Biology, vol. 103, pp. 221-266, 2011.

[51] D. Pilling, T. Fan, D. Huang, B. Kaul, and R. H. Gomer, "Identification of markers that distinguish monocyte-derived fibrocytes from monocytes, macrophages, and fibroblasts," PLoS ONE, vol. 4, no. 10, Article ID e7475, 2009.

[52] S. J. Curnow, M. Fairclough, C. Schmutz et al., "Distinct types of fibrocyte can differentiate from mononuclear cells in the presence and absence of serum," PloS ONE, vol. 5, no. 3, Article ID e9730, 2010.

[53] M. Dominici, K. Le Blanc, I. Mueller et al., "Minimal criteria for defining multipotent mesenchymal stromal cells. The International Society for Cellular Therapy Position Statement," Cytotherapy, vol. 8, no. 4, pp. 315-317, 2006.

[54] M. Crisan, S. Yap, L. Casteilla et al., "A perivascular origin for mesenchymal stem cells in multiple human organs," Cell Stem Cell, vol. 3, no. 3, pp. 301-313, 2008.

[55] A. L. Ford, A. L. Goodsall, W. F. Hickey, and J. D. Sedgwick, "Normal adult ramified microglia separated from other central nervous system macrophages by flow cytometric sorting: phenotypic differences defined and direct ex vivo antigen presentation to myelin basic protein-reactive $\mathrm{CD} 4^{+} \mathrm{T}$ cells compared," Journal of Immunology, vol. 154, no. 9, pp. 43094321, 1995.

[56] A. Hinze and A. Stolzing, "Differentiation of mouse bone marrow derived stem cells toward microglia-like cells," BMC Cell Biology, vol. 12, article 35, 2011.

[57] S. Kaiser, B. Hackanson, M. Follo et al., "BM cells giving rise to MSC in culture have a heterogeneous CD34 and CD45 phenotype," Cytotherapy, vol. 9, no. 5, pp. 439-450, 2007.

[58] F. Deschaseaux, F. Gindraux, R. Saadi, L. Obert, D. Chalmers, and P. Herve, "Direct selection of human bone marrow mesenchymal stem cells using an anti-CD49a antibody reveals their CD45med,low phenotype," British Journal of Haematology, vol. 122, no. 3, pp. 506-517, 2003.

[59] Y. Koide, S. Morikawa, Y. Mabuchi et al., "Two distinct stem cell lineages in murine bone marrow," Stem Cells, vol. 25, no. 5, pp. 1213-1221, 2007.

[60] I. Rogers, N. Yamanaka, R. Bielecki et al., "Identification and analysis of in vitro cultured CD45-positive cells capable of multi-lineage differentiation," Experimental Cell Research, vol. 313, no. 9, pp. 1839-1852, 2007.

[61] B. L. Coles-Takabe, I. Brain, K. A. Purpura et al., "Don't look: growing clonal versus nonclonal neural stem cell colonies," Stem Cells, vol. 26, no. 11, pp. 2938-2944, 2008.

[62] D. R. Davis, Y. Zhang, R. R. Smith et al., "Validation of the cardiosphere method to culture cardiac progenitor cells from myocardial tissue," PLoS ONE, vol. 4, no. 9, Article ID e7195, 2009. 
[63] E. Freisinger, C. Cramer, X. Xia et al., "Characterization of hematopoietic potential of mesenchymal stem cells," Journal of Cellular Physiology, vol. 225, no. 3, pp. 888-897, 2010.

[64] Y. Zhao, D. Glesne, and E. Huberman, "A human peripheral blood monocyte-derived subset acts as pluripotent stem cells," Proceedings of the National Academy of Sciences of the United States of America, vol. 100, no. 5, pp. 2426-2431, 2003.

[65] M. Kuwana and N. Seta, "Human circulating monocytes as multipotential progenitors," Keio Journal of Medicine, vol. 56, no. 2, pp. 41-47, 2007.

[66] H. Kodama, T. Inoue, R. Watanabe et al., "Neurogenic potential of progenitors derived from human circulating $\mathrm{CD} 14^{+}$ monocytes," Immunology and Cell Biology, vol. 84, no. 2, pp. 209-217, 2006.

[67] H. Kodama, T. Inoue, R. Watanabe et al., "Cardiomyogenic potential of mesenchymal progenitors derived from human circulating CD14 ${ }^{+}$monocytes," Stem Cells and Development, vol. 14, no. 6, pp. 676-686, 2005.

[68] P. Romagnani, F. Annunziato, F. Liotta et al., "CD14+CD34 $4^{\text {low }}$ cells with stem cell phenotypic and functional features are the major source of circulating endothelial progenitors," Circulation Research, vol. 97, no. 4, pp. 314-322, 2005.

[69] H. Ungefroren and F. Fändrich, "The programmable cell of monocytic origin (PCMO): a potential adult stem/progenitor cell source for the generation of islet cells," Advances in Experimental Medicine and Biology, vol. 654, pp. 667-682, 2010.

[70] U. Johansson, I. Rasmusson, S. P. Niclou et al., "Formation of composite endothelial cell-mesenchymal stem cell islets: a novel approach to promote islet revascularization," Diabetes, vol. 57, no. 9, pp. 2393-2401, 2008. 

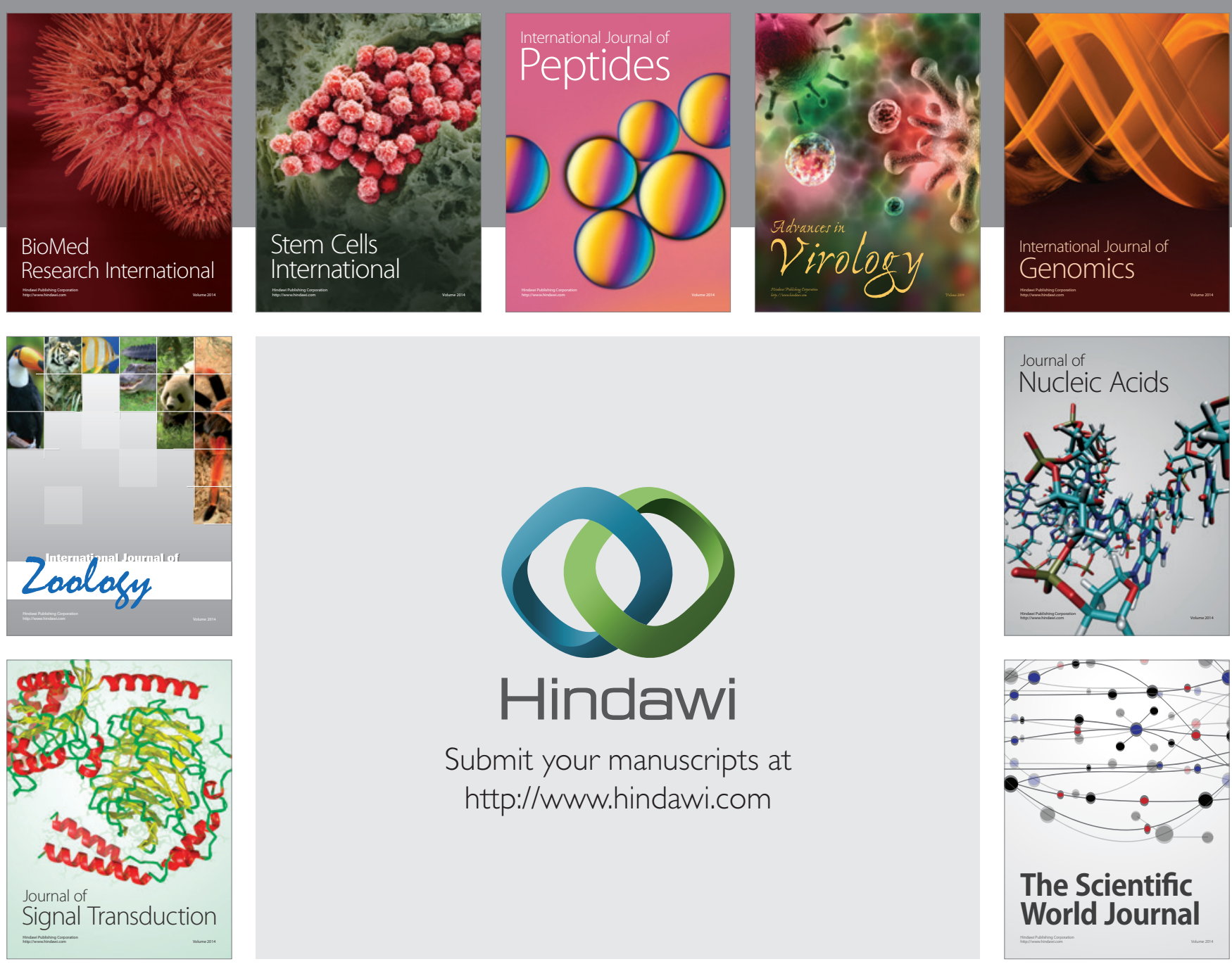

Submit your manuscripts at

http://www.hindawi.com
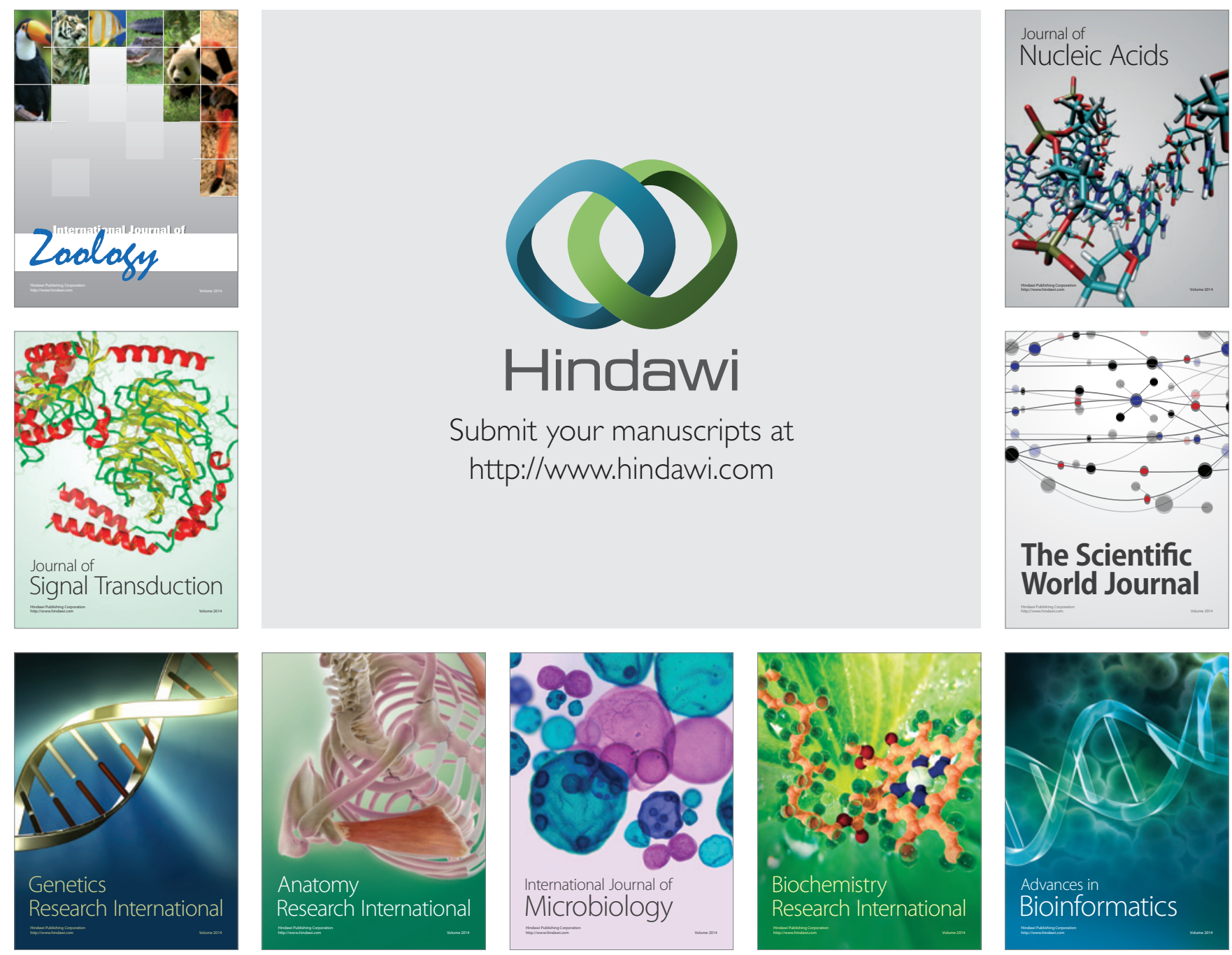

The Scientific World Journal
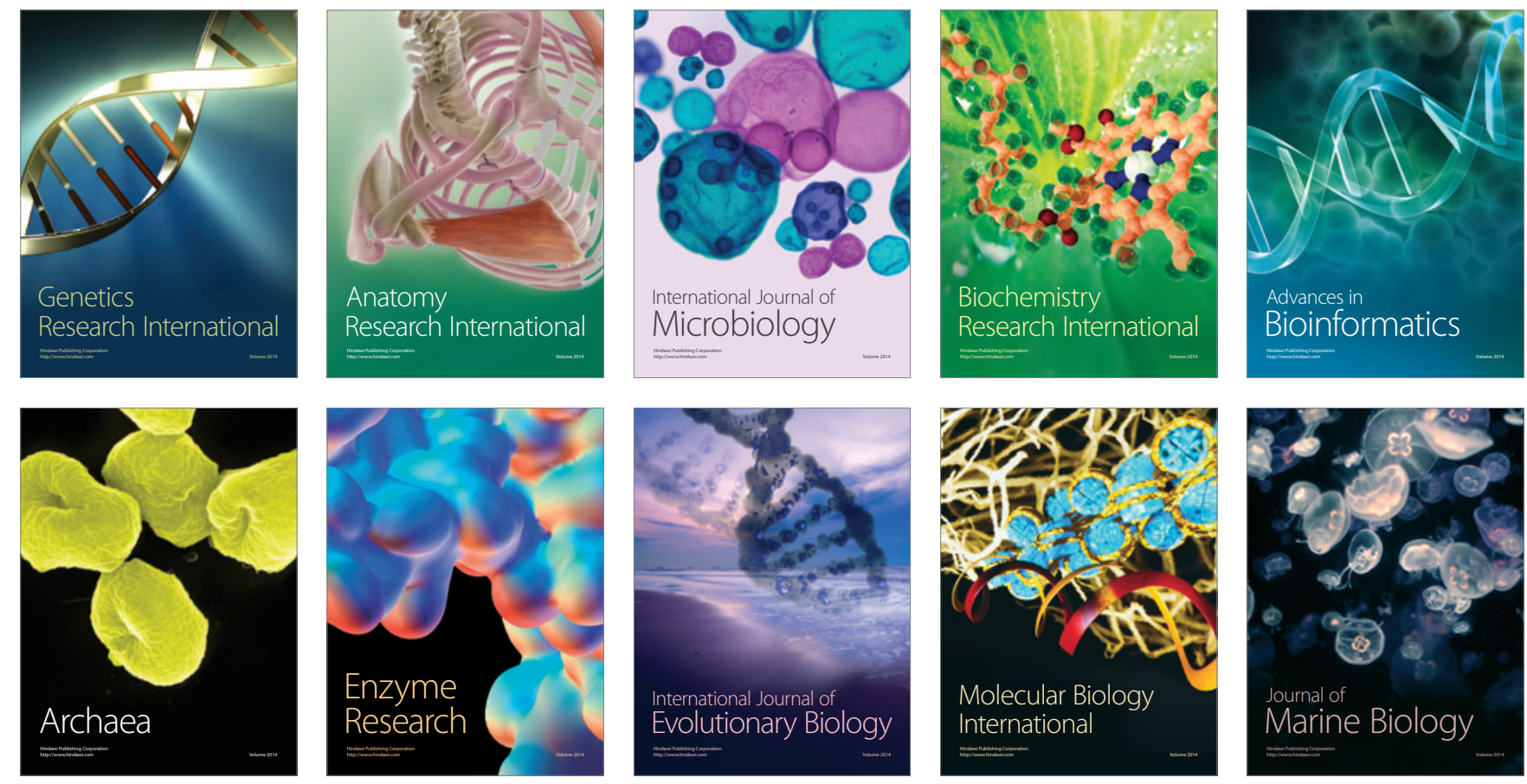